\title{
The Demise of Traditional Technology and Engineering Education Teacher Preparation Programs and a New Direction for the Profession
}

\author{
Kenneth Volk
}

\begin{abstract}
For nearly 40 years, there has been a serious decline in the number of new technology and engineering education teachers and teacher preparation programs in the United States (Akmal, Oaks, \& Barker, 2002; Daugherty \& Boser, 1993; Edmunds, 1980; Greene, 2016; Moye, 2009; Volk, 1993). Currently, only $15 \%$ of the technology and engineering education degreegranting university programs remain since 1970, with nearly half of those remaining barely surviving with three or fewer students graduating annually (Rogers, 2017; Wall, 1970). Perhaps most telling about the health of technology and engineering education is the following question: With nearly half the states no longer having a technology and engineering education teacher preparation program, how can it continue to be considered a "legitimate" subject to be taught in schools?

Declines in the number of technology and engineering education teachers and teacher preparation programs since the 1970s show no signs of abating. There are several reasons for this continued decline. First, the transformation of technology and engineering education programs to industrial technology and engineering eliminated the need to accommodate the preparation of teachers or continue their past mission. Second, those few technology and engineering education programs that still exist may not reflect the reality of many school programs, creating a mismatch between content and expectations when recruiting new student teachers. Finally, with justifications for technology and engineering education and its inclusion in the broader science, technology, engineering, and mathematics (STEM) umbrella being based on economic justifications and national standards, there has been an increase in corporatedriven and foundation-sanctioned technology and engineering education programs. Of particular focus is Project Lead the Way (PLTW), who's training for their program (product) reduces the need for traditional technology and engineering education teacher preparation programs.
\end{abstract}


This article first examines recent trends in technology and engineering education teacher preparation programs in the United States, including the number of graduates and university programs available. Following a discussion of the aforementioned impacts on technology and engineering education teacher programs, a summation is provided, contending that the few traditional teacher preparation programs that remain are in jeopardy and that new teachers in technology and engineering education will likely come through alternative means such as PLTW.

Keywords: Alternative certification; teacher preparation; technology and engineering education; university programs.

\section{Trends in Traditional Technology and Engineering Education Teacher Preparation Programs}

To examine trends in preparing technology and engineering education teachers, data from past studies (Volk, 1993, 1997, 2003) were updated with program information contained in the Technology and Engineering Teacher Education Directory (Rogers, 2010, 2015, 2017; Schmidt \& Custer, 2005). From 1970, Directories were used at 5-year intervals to report the number of technology and engineering bachelor's degrees awarded for each university listed, with the 2017 Directory included to provide the most recent data. Although there have been reservations as to the comprehensiveness and therefore accuracy of the data contained in the Directories (Litowitz, 2014), they continue to be a common resource for studies that rely on university teacher preparation program data (Harris, 2008; Litowitz, 2014; Moye, 2017; Oaks \& Leopp, 1989).

To address Litowitz's concerns and to help validate numbers recorded in the most recent Directory (Rogers, 2017), email letters were sent to 21 faculty members listed in the 2017 Directory. Faculty were identified to be contacted if their programs were missing from the most recent Directory but listed in the 2005 or 2010 Directories. Universities that reported combined degrees such as technology education and agriculture and universities that had wide variations between current seniors and graduate numbers were also contacted to obtain more accurate data. Of particular interest were the large population states of Florida, Texas, and California that had either no program or one program reported.

From the Directory numbers and confirmations through correspondence, it was determined that in 2017, 158 students graduated with undergraduate degrees to teach technology and engineering education. California does not produce teachers with undergraduate degrees, so the number of teachers certified through a university program was obtained through their Educator Preparation Committee (2017) that reports newly certified teachers. The Committee reported six student teachers from all universities in the state. Using Directory numbers 
and the aforementioned verifying sources, the best estimate for new technology and engineering education teachers being produced through traditional university teacher preparation programs in 2017 was 164 .

Concerns raised by Dugger (2007) and Moye (2017) in their research to determine the status, supply, and demand of technology and engineering education teachers indicated that university contacts were not easily identifiable or that feedback was not universally obtained. However, in this study, the majority of faculty members contacted were quick to reply, their responses were detailed, and, in many ways, they were very personal in describing the situation at their respective universities.

As shown in Figure 1, the downward trend that has been occurring since the mid-1970s is continuing. In fact, the current number of technology and engineering education teachers graduating from universities can best be described as paltry. Using Ernst and William's (2015) robust estimation of 46,730 technology and engineering education teachers nationwide and the National Center for Education Statistics' (2018) data suggesting that approximately $7 \%$ of the total teachers leave each year (with $2.2 \%$ of the total retiring), over 3,000 new technology and engineering education teachers would be required to meet this demand. Even using Dugger's (2007) more conservative estimate of 25,000 to 35,000 technology and engineering education teachers, over 1,700 teachers would be needed to replace those leaving each year. Clearly, 164 new teachers are not enough to replace the number of teachers retiring or just leaving teaching. Alternative certification routes that use other subjectmatter teachers or those having a relevant bachelor-level degree to teach technology and engineering education in schools are certainly options that might help meet new teacher demand. Alternative certification will be discussed later.

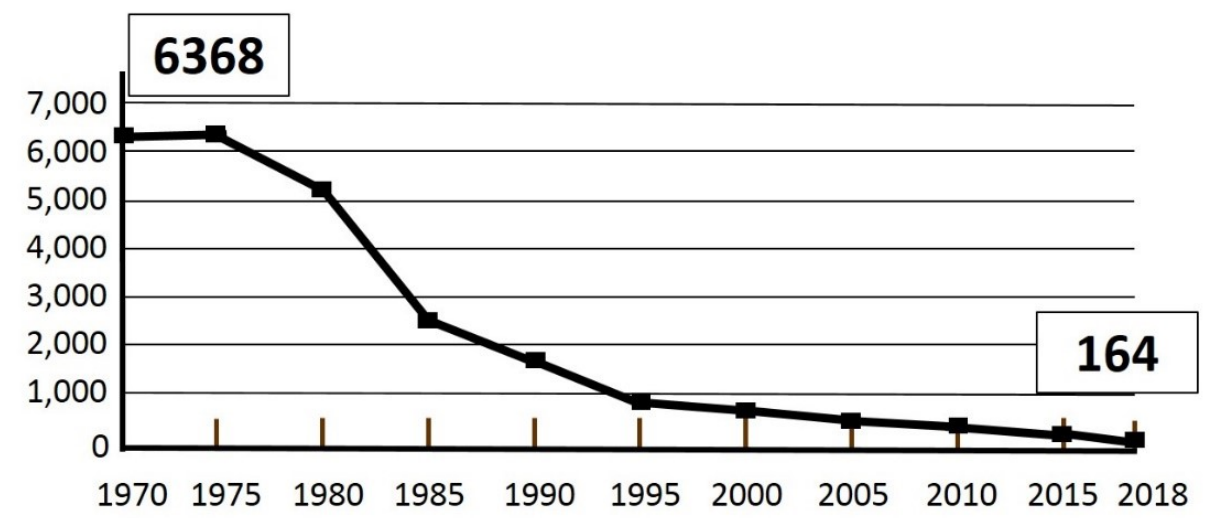

Figure 1. The number of bachelor's degree graduates in technology and engineering education. 
The number of universities with programs in technology and engineering teacher education (or similar) was also examined. As shown in Figure 2, the number of programs remaining is very small, with many states having no program at all. This is particularity concerning in large population states like Florida for those seeking a technology and engineering education teaching degree. Florida A\&M was the last university left in the state that prepared technology and engineering education teachers and was not able to use this fact as justification to keep the program open (D. White, personal communication, November 23, 2017). Of the 32 universities found to still have programs, nearly half (14) reported three or fewer graduates, hardly a sign of strength or permanence. Correspondence received from colleagues at universities with programs now closed suggested that alternate certifications were not satisfying schools' needs or may not be producing the quality of teachers expected. Several colleagues also lamented "the good old days" and suggested that program changes that moved the focus onto engineering and away from teaching were not appealing to or attracting new technology and engineering education students.

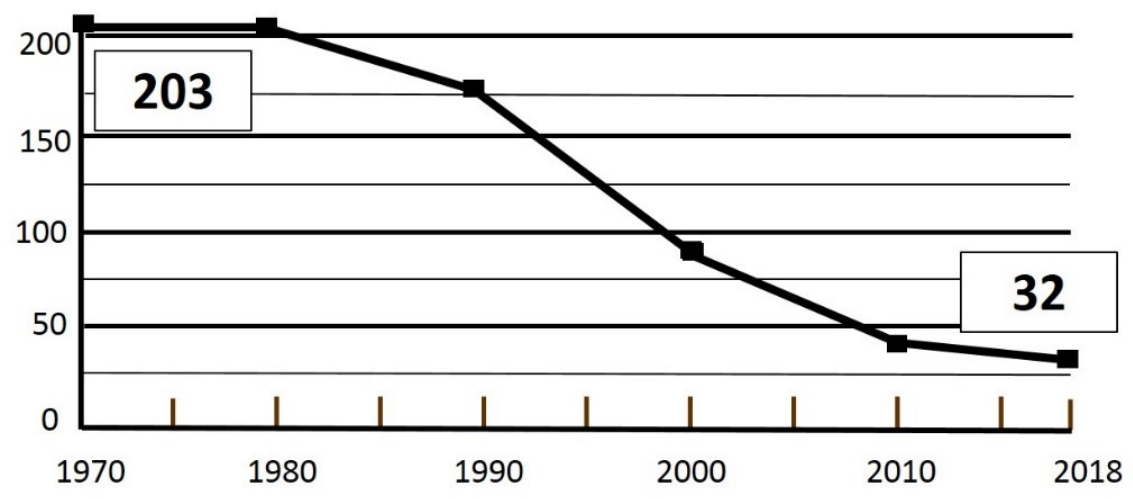

Figure 2. The number of universities preparing technology and engineering education teachers $(\mathrm{BA} / \mathrm{BS})$.

Once programs are gone, they do not come back. An admirable attempt was made in 2004 at St. Petersburg College in Florida to start a new program; however, it soon closed in 2012 due to low enrollment (St. Petersburg, 2018). Although not completely dead, with less than 200 new teachers graduating annually from university technology and engineering education programs, combined with the small number of viable university programs remaining, technology and engineering education teacher preparation programs could be considered on life support. 


\section{Focus on Engineering, Not Teacher Preparation}

The vast majority of the over 200 teacher preparation programs identified in the 1970 Directory are now exclusively engineering or industrial technology programs. From the 32 remaining universities identified with technology and engineering education programs, their programs are housed in a college of professional studies (41\%) or in a college of engineering/technology (59\%). Only a few of the technology and engineering education programs offered through a college of professional studies, such as the State University of New York College at Oswego, provide both professional studies and technical courses. Now, most programs only provide the professional studies component.

Having the technical courses provided by a college or department outside the actual professional studies program's home may impact program emphases, faculty allegiances, and faculty's professional contributions. In Brown's (2017) study of the number of general education and technical courses students in technology and engineering education teacher preparation programs take, he found no significant differences between programs housed in education departments and programs in noneducation departments. He attributed this to state licensing standards and controls setting the number of general education courses required. However, one caveat of Brown's findings was the possibility of challenges or impacts on other aspects of the program or faculty housed in noneducation departments, such as resource allocation, faculty expertise, and morale.

For teacher preparation programs that are now a minor component in a college or department of engineering, these challenges have been acknowledged. Batey's (2018) description of Texas State University's Department of Engineering Technology transformation from an industrial arts program illustrates this predicament. Originally an Industrial Arts Department located in a teachers' college that prepared industrial arts teachers and provided some preengineering courses, in 1985, the department was renamed the Department of Technology and moved from the School of Education to the School of Applied Arts and Technology. With this move and change in name, the new focus was on preparing professional managers for industry rather than focusing on teacher education. More simply put, courses like woods, metals, drafting, and electronics don't fit well with the university's Research I model (A. Batey, personal communication December 6, 2018).

The increased focus on engineering and not teacher education in universities also impacted professional dialog. For example, in 1973, the National Association of Industrial Technology Teacher Education (NAITTE) had over 700 members, but by 2004, it had declined to 182 (Gagel, 2006). With declining membership, NAITTE broadened its scope in 2010 and changed its name to the Association of STEM Teacher Education (ASTE). Their journal, first published in 1963, also changed from the Journal of Industrial Teacher Education (JITE) to the Journal of STEM Teacher Education. Unfortunately, the effort to maintain 
contributions only lasted 2 years, and their budget balance was transferred to the Association for Career and Technical Education's eTED division for scholarships (G. Rogers, personal communication, July 15, 2018). Their sponsorship of the Industrial Teacher Education Directory also ended, leaving that responsibility to rest solely upon the International Technology and Engineering Educators Association's (ITEEA) affiliate Council on Technology Teacher Education (CTTE).

The Journal of Industrial Teacher Education was not alone in changing its scope because the audience had changed since its original mission. Since 1974, the Journal of Epsilon Pi Tau bore the name of the parent honorary organization but changed its name to The Journal of Technology Studies in 1993. Although the Board debated this change for 10 years (Streichler, 1993), they finally agreed that it was needed to reflect an audience wider than the field of education and that the new title "would not put off potential contributors" (p. 2). Today, the majority of the articles in The Journal of Technology Studies still focus on education, but some are now strictly technical.

\section{Teacher Preparation Programs Not Matching the Reality of Schools}

With most technology and engineering education teaching programs now transitioned to engineering and traditional school technology and engineering education courses such as woodworking and metalworking not seen as relevant, appropriate, or reflecting modern technology (International Technology Education Association [ITEA], 2007), there may be a mismatch between the type of technology and engineering education teacher being produced and what's actually still being taught in schools. It is also possible that prospective student teachers are not attracted to the new technology and engineering education teacher preparation programs. Simply put, students who went through more traditional school programs that are still very prevalent (Kelley \& Wicklein, 2009; Rigler, 2017; Sanders, 2001) may be more attuned to be industrial arts teachers. For many years, it has been recognized that teachers, enjoying the course, and hobbies are the strongest influences for students to enroll in a technology and engineering education teacher preparation program (Beauter, 1984; Donnell, 1975; Freeland, 2013; Harris, 2008; Weber, 2011; Wright \& Custer, 1998). There is anecdotal and empirical evidence that this is true today.

Welty (2016) described the mismatch in what prospective technology and engineering education teachers studied in his university's program and what he observed during their student-teacher supervision. Despite preparing technology and engineering education teachers with specific subject-matter skills and philosophy, he noted, "I spent last Tuesday observing metalworking classes. Tomorrow I will be observing woodworking and metalworking. This Tuesday, I will spend the morning in a welding lab." In this way, Welty suggested this was a good way to figure out "who we [really] are today." What was observed in 
Wisconsin is not an isolated case. School fairs in California, Iowa, Kansas, Minnesota, Montana, Texas, and other states still proudly showcase students' projects in metalwork and woodworking.

In presenting best practices to recruit technology and engineering education teachers, Love, Love, and Love (2016) profiled Pennridge High School in Pennsylvania and Allen Androkites' success in having 28 of his former students become teachers during his 35 years of teaching. Androkites' program was recognized as an ITEEA Program of Excellence in 2018; however, when his program is examined, it would be considered traditional industrial arts and not technology and engineering education. The Pennridge High School program has four levels of woodworking, two classes in metals, five in drafting, one in robotics, and a noted class in guitar building (Pennridge, 2017). Although many students must have enjoyed their courses and teachers in the Pennridge High School program, like in countless other schools throughout the United States influencing them to become a teacher, some would probably be surprised and disappointed to not find the industrial arts courses that they are familiar with in any university's technology and engineering education teacher preparation or engineering program. A mismatch between what is actually occurring in schools (Rigler, 2016, 2017) and what professional associations such as ITEEA and universities profess should be occurring may be discouraging to those entering the teaching profession.

\section{Alternative Certification Meeting Shortages?}

Alternative certification paths for new technology and engineering education teachers have been recognized as a way to alleviate teacher shortages, with teachers licensed through means other than through a traditional universitybased teacher preparation program (Hoepfl, 2001). In a nationwide comprehensive review of teachers using the Schools and Staffing Survey (SASS) administered by the U.S. Department of Education, Ernst and Williams (2015) found that technology and engineering education teachers are more likely to receive certification through an alternative certification program than other teachers $(21.6 \%$ vs. $14.5 \%)$.

Every state now views alternative certification as a valuable and necessary means to address teacher shortages (National Education Association, 2016). For example, Texas has seen the number of alternatively certified career and technical education teachers double since 2008 to over 1,200 in 2017 (Texas Education Reports, 2018). Prospective technology and engineering education teachers in Texas can choose from 45 Education Preparation Providers to obtain their teaching credentials (Texas Education Agency, 2019). Providers include local school districts, universities, and organizations such as A+Texas, iteachTEXAS, Teacher Builder, and Teachers for the $21^{\text {st }}$ Century. It must be noted that the universities listed by the Texas Education Agency now have 
defunct technology and engineering education teacher preparation programs and thus use their School of Education courses.

Although some alternative certification programs may dovetail into existing university teacher preparation programs, as is the case in Texas, providers such as community colleges, for-profit corporations, or even local school districts can supply the required professional content without any university connection. Simply put, alternative certification programs will do little to preserve traditional technology and engineering education teacher preparation programs.

Several studies pointed to differences between the preparation of the two groups of teachers. For example, traditionally certified teachers were perceived by principals to be better prepared and effective (Bartholomew, Bullock, \& Nadelson, 2018). A concern raised by Strimel and Grubbs (2016) was that technology and engineering education teachers coming through nontraditional certification programs did not fully understand technology and engineering education. This could have implications as to alternatively certified teachers' understanding of the history, philosophy, rationale, challenges, and situational contexts of technology and engineering education. Finally, although alternative programs may be addressing teacher shortages, those prepared through such routes leave the profession at higher rates than those completing a traditional program (Harris, Camp, \& Adkison, 2003). This may be leaving schools facing the recurring problem of frequently having to recruit teachers, and if recruitment is low, their technology and engineering education programs may just close.

\section{Teachers Certified for Corporate Curriculum}

Corporate involvement in technology and engineering education curriculum and teacher preparation is not new. As early as the mid-1960s, the Industrial Arts Curriculum Project enlisted the help of industry to develop a structure and accompanying teaching activities, guides, and manuals (Andrews, 1984). A few years later, the World of Construction (Industrial Arts Curriculum Project [IACP], 1970) and the World of Manufacturing (IACP, 1971) instructional materials were produced through this project. In-service workshops for teachers wanting to transition their traditional junior high school program were also made available but were not required to teach the program.

Gaining popularity in the 1980s was the so-called "modular approach" that utilized vendor-produced equipment for students to then rotate through prescribed activities. As noted by Petrina (1993), such programs represent "a divestiture of control and authority from a domain of technology teacher education, and a conceding of that authority to product companies and their operational context of corporate economics and politics" (p. 75). Companies providing modular equipment like Graves-Humphreys, Synergistic, Marcraft, and Hearlihy would supply teachers with amenities that included instructor's notes, daily activities, tests, and even information on how to acquire funding to purchase their equipment. Although training on how to use the modules would 
have been offered to teachers at gatherings such as the International Technology Education Association's (ITEA) annual conference, it was not required by vendors as a prerequisite to use their product.

Herschbach's (2009) contention that the philosophical shift from industrial arts to technology in the 1980s was largely based on political agendas and economic competition facing the United States is even more prevalent today with the justification and call for technology and engineering education in STEM education. ITEEA's renamed Technology and Engineering Teacher (TET) journal regularly features articles that justify technology and engineering education on economic competitiveness grounds (Bybee, 2010; Christman, 2012; Flanigan, Becker, \& Stewardson, 2012; Hughes, 2010; Roberts, 2013; Strimel, Grubbs, \& Wells, 2017).

ITEEA's Engineering byDesign ${ }^{\mathrm{TM}}$ curriculum is based on national standards but also acknowledges its contribution to U.S. economic competitiveness, with the program helping students to "understand why technology and its use is such an important force in our economy" (ITEA, 2006, p. 3). Although each school grade is structured on thematic units, teachers are not required to use a standard activity, instructional approach, tools, or materials. Professional training and certification are not specifically required to teach Engineering byDesign ${ }^{\mathrm{TM}}$, but ITEEA's STEM Center for Teaching and Learning offers teachers opportunities for sharing strategies with collaborative online communities and fee-paying summer institutes. These institutes may be using faculty from technology and engineering education teacher training institutes, but more often, they are just experienced teachers.

A more serious threat to the continued existence of the small number of technology and engineering education teacher training institutes remaining is Project Lead the Way (PLTW). Started in 1997 by a few schoolteachers in upstate New York, PLTW has grown into a large nonprofit organization that provides curriculum and instructional materials to over 11,000 schools to teach technology and engineering education within the larger realm of STEM. "As a 501(c)(3) charitable organization, PLTW exists to prepare students for the global economy" (Bertram, 2013, p. 1). Positioned as a way to teach engineering in schools, PLTW promotes and advertises commissioned research to validate claims of success (Tai, 2012), utilizes public relations firms costing over one million dollars a year to promote (sell) their product (GuideStar, 2016, Part VII, Section B), and partners with Fortune 500 corporations, local businesses, and foundations such as the Kern Family Foundation (Project Lead the Way [PLTW], 2019a). With the CEO's total compensation of nearly $\$ 750,000$ a year and salaries of over $\$ 200,000$ a year for all eight officers (GuideStar, 2016, Part VII, Section A), PLTW has quickly grown to an educational behemoth that is usurping the need for traditional technology and engineering education teacher training institutes. Professional organizations that represent technology and 
engineering education, such as ITEEA, are at a disadvantage and certainly do not have the same size, clout, or compensation package.

With the growth and reach of PLTW, it is becoming difficult for traditional programs to compete or even remain relevant. For example, in order to be certified to teach PLTW, teachers are required to attend a prescribed PLTW training program. Most of the sites used are not associated with technology and engineering education teacher training institutes but rather engineering schools with engineering faculty contracted by PLTW to conduct workshops. With costs ranging from $\$ 500$ for a 1-day workshop to $\$ 2,400$ for 2 weeks, PLTW has a captive audience of teachers certified in any subject area being able to teach their program. To date, over 55,000 teachers have gone through one of their programs specifically designed for each of their specialized programs (PLTW, 2019b). Similar to companies such as McDonald's, Walmart, or Starbucks whose customers recognize and expect a standard product no matter the location, PLTW's customers expect their product to be the same; however, their customers are teachers, administrators, students, and the public.

Encouraging schools to adopt the program, PLTW generously provides grants for teacher training or for the purchasing of equipment needed to teach the program. Many corporations such as Intel, Lockheed Martin, and Chevron have also provided resources to establish PLTW in schools. In 2016, PLTW provided over $\$ 8,000,000$ in grants to "domestic organizations and domestic governments" (GuideStar, 2016, Part I, Line 13), but for their business model, received over $\$ 43,000,000$ in revenue (GuideStar, 2016, Part I, Line 12), through equipment purchases, training, and annual participation fees that schools must pay. If a PLTW-trained teacher leaves the school district, they will provide a grant to the school in order to train another teacher, thus keeping the program and annual fees going. With PLTW using a seamless approach of providing the instructional material, teacher training, and complete equipment packages for schools to purchase, traditionally prepared technology and engineering education teachers (and their programs) have become less significant and perhaps even less marketable. Online employment search sites such as Indeed.com and Monster.com regularly advertise for PLTW-trained teachers not technology and engineering educators.

Despite creating an educational product that requires training for any certified subject-matter teacher to use their product, PLTW's CEO publically questioned the value and necessity of traditional teacher preparation programs (Bertram, 2015). Bertram states that schools have made great strides providing quality STEM education, but "outdated teacher qualification standards in many states make it difficult to find teachers who are trained and experienced in these subjects" (para. 1). He goes on to say that state leaders and legislators should address restrictive policy barriers: 
One of these barriers exists in the form of state teacher certification requirements that often prohibit experienced STEM professionals from teaching high school or middle school courses in their areas of expertise without having to take additional, often unrelated, coursework. (para. 8)

As "a national nonprofit organization dedicated to STEM curriculum and teacher training" (para. 10), having a wider pool of potential customers for their product would be welcome. By advocating an easier route to teach PLTW, the company would not need to rely on certified teachers to then be PLTW trained and approved, thus eliminating technology and engineering education programs as well as any traditional or alternative certifications programs from the equation.

\section{Conclusion}

The school subject of technology and engineering education has gone through many changes over the years, not only in name, rationale, and content but in how teachers are prepared. Besides a traditional teacher preparation program, today, alternative certification is another option to prepare teachers. Outside forces such as standards, economic imperatives, and perceptions of teaching as a career have impacted the recruitment of all subject-matter teachers, but technology and engineering education has been particularly hard hit. Traditional technology and engineering education teacher preparation programs have been changed to focus on engineering, and these changes are affecting the continuation and viability of those few programs remaining.

Instructional trends like the "modular approach" required a shift in the type of technology and engineering education teacher because their role was more of a facilitator using vendor-supplied notes, activity guides, and tests. Although this approach was different than what was traditionally practiced, it did not specifically impose new teacher training in order to use the vendor's product. This has significantly changed with Project Lead the Way.

Although many members of a community would embrace the arrival of a McDonald's, Walmart, or Starbucks as a sign of respectability, status, and economic modernity, others would view such an "achievement" as a threat to local control, the local economy, and local traditions. In many ways, PLTW is similar, ending years of tradition to welcome a brand name that's touted by corporations, politicians, and educators as a way to develop engineers in order for the United States to compete economically. It may not be too difficult convincing a public about the value of PLTW - a public who is already skeptical about the quality of their schools and teachers. The growth of PLTW has certainly been impressive and will no doubt last a lot longer than the modular approach. Also, with the teacher training and equipment investments made and annual fees required for schools to maintain their stamp of approval for an 
assumed quality (student) output, it will be difficult for any school administration to later justify the decision to terminate the program.

Although PLTW now uses certified teachers in any subject to be trained to use their product, PLTW will more likely need to train uncertified teachers to meet increased program demand, as previously suggested by their CEO (Bertram, 2015). In a way, once PLTW makes its way into a community's school, a professionally certified teaching professional will not be required, just a person trained to order stock, greet people at the door, and fill a cup according to a canned activity's instructions and company specifications.

With Perkins funds being made available for equipment and leadership development, which will certainly be used to implement and support the continuation of PLTW in schools, there is even more certainty about PLTW's permanence and increased influence. Perhaps this new direction is inevitable. Most technology and engineering education teacher preparation programs are now closed, the few remaining programs are under great pressure because of low student numbers, and no new programs have been started. Traditional technology and engineering teacher education is following the path of subjects such as Latin and Philosophy - subjects that once needed universities to produce specialized, trained, and highly qualified teachers. Sadly, these programs are no longer relevant and, for the most part, long gone. Requiescat in Pace.

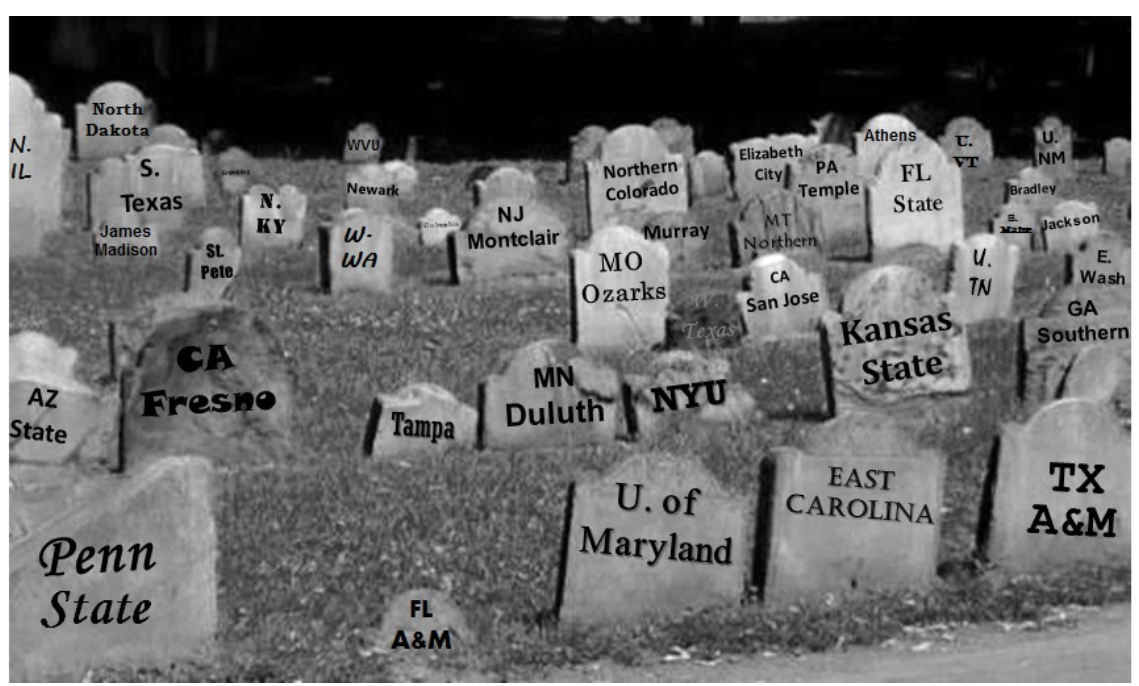

Figure 3. RIP: University programs long gone. 


\section{References}

Akmal, T., Oaks, M., \& Barker, R. (2002). The status of technology education: A national report on the state of the profession. Journal of Industrial Teacher Education, 39(4). Retrieved from https://scholar.lib.vt.edu/ejournals/JITE/v39n4/akmal.html

Andrews, R. C. (1984). Program design models in industrial arts teacher education and certification: A national status study (Doctoral dissertation, University of Massachusetts, Amherst). Available from https://scholarworks.umass.edu/dissertations_1/3930

Bartholomew, S.; Bullock, E.; \& Nadelson, L. (2018). A route less traveled: Principals' perception of alternative licensed CTE teachers. Journal of Education and Training, 5(2), 12-20. doi:10.5296/jet.v5i2.12503

Batey, A. (2018, December 5). A brief history of the department of engineering technology. Available from https://www.txstate.edu/technology/about/history.html,

Beauter, R. (1984). An analysis of the reasons and influences causing students to enroll in industrial arts education programs at Virginia universities (Master's thesis, Old Dominion University). Available from https://digitalcommons.odu.edu/ots_masters_projects/457

Bertram, V. (2013, March 13). Testimony of Dr. Vince Bertram Project Lead the Way President and CEO Before the House Committee on Science, Space and Technology Subcommittee on Research. Retrieved from https://docs.house.gov/meetings/SY/SY14/20130313/100506/HHRG-113SY14-Wstate-BertramV-20130313.pdf

Bertram, V. (2015, August 12). States taking the lead on STEM education. Retrieved from https://www.foxnews.com/opinion/states-taking-the-leadon-stem-education

Brown, R. (November 16, 2017). Does the rhetoric emulate the reality? Paper presented at the Mississippi Valley Technology Teacher Education Conference, $104^{\text {th }}$ Conference, St. Louis, MO.

Bybee, R. (2010). Advancing STEM education: A 2020 vision. Technology and Engineering Teacher, 70(1), 30-35, Retrieved from http://www.iteea.org/Publications/TTT/sept10.pdf

Christman, S. (2012). Preparing for success through apprenticeships. Technology and Engineering Education, 71(1), 22-28. Available from: http://www.iteea.org/Publications/TTT/sept12.pdf

Daugherty, M., \& Boser, R. (1993). The recruitment imperative: Replacement or displacement. The Technology Teacher, 52 (7), 31-32.

Donnell, R. (1975). The recruiting of prospective teachers of industrial arts education (Master's thesis, North Texas State University, Denton). Retrieved from https://Digital.library.unt.edu/ark:67531/metadc663703/m1/1 
Dugger, W. (2007). The status of technology education in the United States: A triennial report of the finding from states. The Technology Teacher, 67(1), $14-21$.

Edmunds, N. A. (1980). Effective recruiting -A tool to replenish, sustain, and improve the profession. The Journal of Epsilon Pi Tau, 6 (1), 17-22.

Ernst, J., \& Williams, T. (2015). The "who, what, and how conversation": Characteristics and responsibilities of current in-service technology and engineering educators. The Journal of Technology Studies, 41(1), 48-57. doi:10.21061/jots.v41i1.a.6

Flanigan, R., Becker, K., \& Stewardson, G. (2012). A contemporary preservice technology education program. Technology and Engineering Education, 72(2), 25-29. Retrieved from http://www.iteea.org/Publications/TTT/oct12.pdf

Freeland, T. (2013). Why do Indiana pre-service technology education majors choose the profession (Master's thesis, Purdue University). Retrieved from http://docs.lib.purdue.edu/techmasters/82

Gagel, C. (2006). National Association of Industrial Technology Teacher Education membership survey report: Comparison of 1993 and 2004 surveys. Journal of STEM Teacher Education, 43 (1), 8-45. Available from https://ir.library.illinoisstate.edu/jste/vol43/iss1/

Greene, C. (2016, March). Technology teachers needed: The current state of technology teacher education programs in New York State. Paper presented at the ITEEA conference, Washington, DC.

GuideStar. (2016). Return of organization exempt from income tax: Project Lead the Way Inc. [2016 IRS form 990]. Retrieved from https://pdf.guidestar.org/PDF_Images/2017/141/816/2017-1418163850eb2da90-9.pdf

Harris, K. (2008, June). Recruitment in engineering/technology teacher education: Factors that influence females. Paper presented at 2008 Annual Conference \& Exposition of the American Society for Engineering Education, Pittsburgh, PA. Retrieved from https://peer.asee.org/3443

Harris, S. A., Camp, W. E., \& Adkison, J. (2003, January). New structures and approaches for teacher preparation: Do they make a difference in teacher retention? Paper presented at the meeting of the American Association of Colleges for Teacher Education, New Orleans, LA. Retrieved from https://eric.ed.gov/?id=ED472813.

Herschbach, D. (2009). Technology education foundations and perspectives. Homewood, IL: American Technical Publishers.

Hoepfl, M. (2001). Alternative routes to certification of technology education teachers. Journal of Technology Studies, 27(1-2), 74-83.

doi:10.21061/jots.v27i2.a.2 
Hughes, B. (2010). Park Forest middle school STEM education fair 2010, Technology and Engineering Teacher, 70(2), 32-35. Retrieved from http://www.iteea.org/Publications/TTT/oct10.pdf.

Industrial Arts Curriculum Project. (1970). The world of construction. Bloomington, Illinois: McKnight and McKnight.

Industrial Arts Curriculum Project. (1971). The world of manufacturing. Bloomington, Illinois: McKnight and McKnight.

International Technology Education Association. (2006). Engineering by design: A standards-based model program. Retrieved from https://www.iteea.org/file.aspx?id=37613

International Technology Education Association. (2007). Standards for technological literacy: Content for the study of technology (3rd ed.). https://www.iteea.org/file.aspx?id=37613

Kelley, T., \& Wicklein, R. C. (2009). Examination of assessment practices for engineering design projects in secondary technology education. Journal of Industrial Teacher Education. 46(1), 6-31.

Litowitz, L. (2014). A curricular analysis of undergraduate technology \& engineering teacher preparation programs in the United States. Journal of Technology Education, 25(2), 73-84. doi:10.21061/jte.v25i2.a.5

Love, T., Love, Z., \& Love, K. (2016). Better Practices for Recruiting T\&E Teachers, The Technology Teacher, 76 (1), 10-15.

Moye, J. J. (2009). Technology education teacher supply and demand-A critical situation. The Technology Teacher, 69(2), 30-36.

Moye, J.J. (2017). The supply and demand of technology and engineering teachers in the United States: Who knows? Journal of Technology and Engineering Education, 76(4), 32-37.

National Center for Education Statistics. (2018). Schools and staffing survey. Retrieved from https://nces.ed.gov/surveys/sass/tables/TFS1213_2014077_cf1n_001.asp

National Education Association. (2016). Research spotlight on alternative routes to teacher certification. Retrieved from http://www.nea.org/tools/16578.htm

Oaks, M. M., \& Leopp, F. (1989). The future of technology teacher education. Journal of Industrial Teacher Education, 26(4), 67-70.

Pennridge. (2017). Pennridge Technology Education. Retrieved from http://pennridgeteched.com/intro-to-tech-classes.html.

Petrina, S. (1993) Under the corporate thumb: Troubles with our MATE (Modular Approach to Technology Education). Journal of Technology Education, 5(1), 72-80. doi:10.21061/jte.v5i1.a.6

Project Lead the Way. (2019a). Partnering with PLTW. Retrieved from https://www.pltw.org/our-partners

Project Lead the Way. (2019b). PLTW, state by state. Retrieved from https://www.pltw.org/about-us/pltw-state-presence 
Rigler, K. (2016). A proposition to engineer a bridge: Reconnecting with the industry-based educators. Technology and Engineering Teacher, 76(4), 912.

Rigler, K. L., Jr. (2017). Educators' resistance to the technology and engineering education transition. Journal of Technology Studies, 42(1), 42-53. doi:10.21061/jots.v42i1.a.4

Roberts, A. (2013). STEM is here. Now what? Technology and Engineering Education, 73(1), 20-27. Retrieved from http://www.iteea.org/Publications/TTT/sept13.pdf

Rogers, G. (Ed.). (2010). Technology and Engineering Teacher Education Directory $\left(49^{\text {th }}\right.$ ed.) The Council on Technology and Engineering Teacher Education.

Rogers, G. (Ed.). (2015). Technology and Engineering Teacher Education Directory $\left(54^{\text {th }}\right.$ ed.) The Council on Technology and Engineering Teacher Education.

Rogers, G. (Ed.). (2017). Technology and Engineering Teacher Education Directory. The Council on Technology and Engineering Teacher Education.

Sanders, M. (2001). New paradigm or old wine? The status of technology education practice in the United States. Journal of Technology Education, 12(2), 35-55. doi:10.21061/jte.v12i2.a.3

Schmidt, K., \& Custer, R. (Eds.). (2005). Industrial Teacher Education Directory $\left(44^{\text {th }}\right.$ ed). National Association of Industrial and Technical Teacher Educators and The Council on Technology and Engineering Teacher Education.

St. Petersburg College. (2018). Substantive Change. Retrieved from https://go.spcollege.edu/Substantive_Change/.

Streichler, J. (1993). Falling behind in being ahead ... on titles, missions, and traditions. The Journal of Technology Studies, 19(1), 2-3. Retrieved from http://www.jstor.org/stable/43603601

Strimel, G., \& Grubbs, M. E. (2016). Positioning technology and engineering education as a key force in STEM education. Journal of Technology Education, 27(2), 21-36. doi:10.21061/jte.v27i2.a.2

Strimel, G., Grubbs, M., \& Wells, J. (2017). Engineering education: A clear decision. Technology and Engineering Teacher. 76(4) 32-35. Retrieved from https://www.iteea.org/File.aspx?id=128555

Tai, R. H. (2012). An examination of the research literature on Project Lead the Way. Indianapolis, IN: Project Lead the Way. Retrieved from https://www.pltw.org/dr-robert-tai-report

Texas Education Agency. (2019). Educator preparation programs in Texas: Technology education (Grades 6-12). Retrieved from https://airesri.maps.arcgis.com/apps/opsdashboard/index.html\#/f843bd7cdb 3440b59b0b59b5ba656f85. 
Texas Education Reports. (2018). Teacher certification statewide by certification program: Alternative program. Retrieved from http://texaseducationinfo.org/ViewReport.aspx.

Volk, K. S. (1993). Enrollment trends in industrial arts/technology education programs from 1970-1990. Journal of Technology Education, 4(2), 46-59. doi:10.21061/jte.v4i2.a.4

Volk, K. S. (1997). Going, going, gone? Recent trends in technology teacher preparation programs. Journal of Technology Education, 8(2), 67-71. doi:10.21061/jte.v8i2.a.5

Volk, K.S. (2003). Trends in U.S. technology teacher education programs: Home thoughts from abroad. Journal of Industrial Teacher Education. 37(3), 115-126.

Wall, G. S. (Compiler). (1970). Industrial Teacher Education Directory (9th ed.). South Holland, IL: Goodheart-Willcox.

Weber, K. (2011). Role models and informal STEM-related activities positively impact female interest in STEM. Technology and Engineering Teacher, 71(3), 18-21.

Welty, K. (2016, December 19). Discussion on name change [electronic mailing list]. Message posted to ctete@list.appstate.edu

Wright, T., \& Custer, R. (1998). Why they teach: Factors influencing students to become technology education teachers. Journal of Technology Education, 10(1), 58-70. doi:10.21061/jte.v10i1.a.4

\footnotetext{
About the Author

Kenneth Volk (drkenvolk@yahoo.com) is Director of Outreach Programs at Khalifa University in the United Arab Emirates.
} 